\title{
Preliminary results of pore pressure profiling on theTęgoborze-Just landslide
}

\author{
Jacek Stanisz ${ }^{1, *}$ and Zenon Pilecki ${ }^{2}$ \\ ${ }^{1}$ AGH University of Science and Technology, Krakow, Poland \\ ${ }^{2}$ Mineral and Energy Economy Research Institute, Polish Academy of Sciences, Krakow, Poland
}

\begin{abstract}
In this study, we present the preliminary results of deep profiling of pore pressure in the near surface formations of the Carpathian flysch, on the Tęgoborze-Just landslide near Nowy Sącz in Southern Poland. The aim of the study is to identify zones with significant changes in pore pressure influenced landslide processes. These pore pressure changes correspond to a greater change in the degree of saturation or water flow paths. Profiling was performed in four series using a CPTU static probe with a NOVA Acoustic cone. The measurement of pore pressure in flysch formations is very complicated due to the strong heterogeneity of the medium properties and variable water conditions, which are strongly influenced by the intensity of precipitation. The tests were carried out in a colluvium to a depth of approx. $5.0 \mathrm{~m}$, i.e. to the border of a less weathered bedrock, under varying water conditions. The results obtained indicate the presence of four zones of significant changes in pore pressure. The location of these zone is consistent with the location of the greater displacement measured with the inclinometer. There is a greater probability that these weak zones may form a rupture surface.
\end{abstract}

Key words: pore presure, CPTU sounding, inclinometer, landslide, Carpathian Flysch

\section{Introduction}

Pore pressure profiling provides important information about structure, geologicalengineering properties and physical-mechanical processes occurring in the geological medium [1-4]. Investigations concerning changes in water conditions, including pore pressure, may be related to the development of the landslide process (e.g. [5-8]).

The aim of the study is to identify zones with significant changes in pore pressure near the surface formation of Carpathian flysch influenced landslide processes. These pore pressure changes correspond to a greater change in the degree of saturation or water flow paths. We used static probing of CPTU with a NOVA Acoustic cone. The study was carried out in the colluvium on the Teqgoborze-Just landslide in the south-eastern part of Poland (Fig. $1)$.

\footnotetext{
*Corresponding author: jstanisz@agh.edu.pl
} 
Three typical parts may be distinguished in the geological-engineering profile of the Carpathian flysch: near surface soils, weathering zone and bedrock [9-10]. Near surface soils, generally regarded as quaternary, are related to flysch bedrock, as they have generally formed as a result of its weathering. Their physical and mechanical properties are very variable. In these parts of the flysch medium, landslide processes most often develop [9-11]. The properties of near-surface soils depend on many factors, such as: the type of bedrock, the sort of weathering and the morphology of the slopes. The bedrock is characterized by alternating layers of medium and coarse sandstone and conglomerates as well as fine-grained siltstones and claystones with other kinds of rocks (marls, hornstones) [12-13].
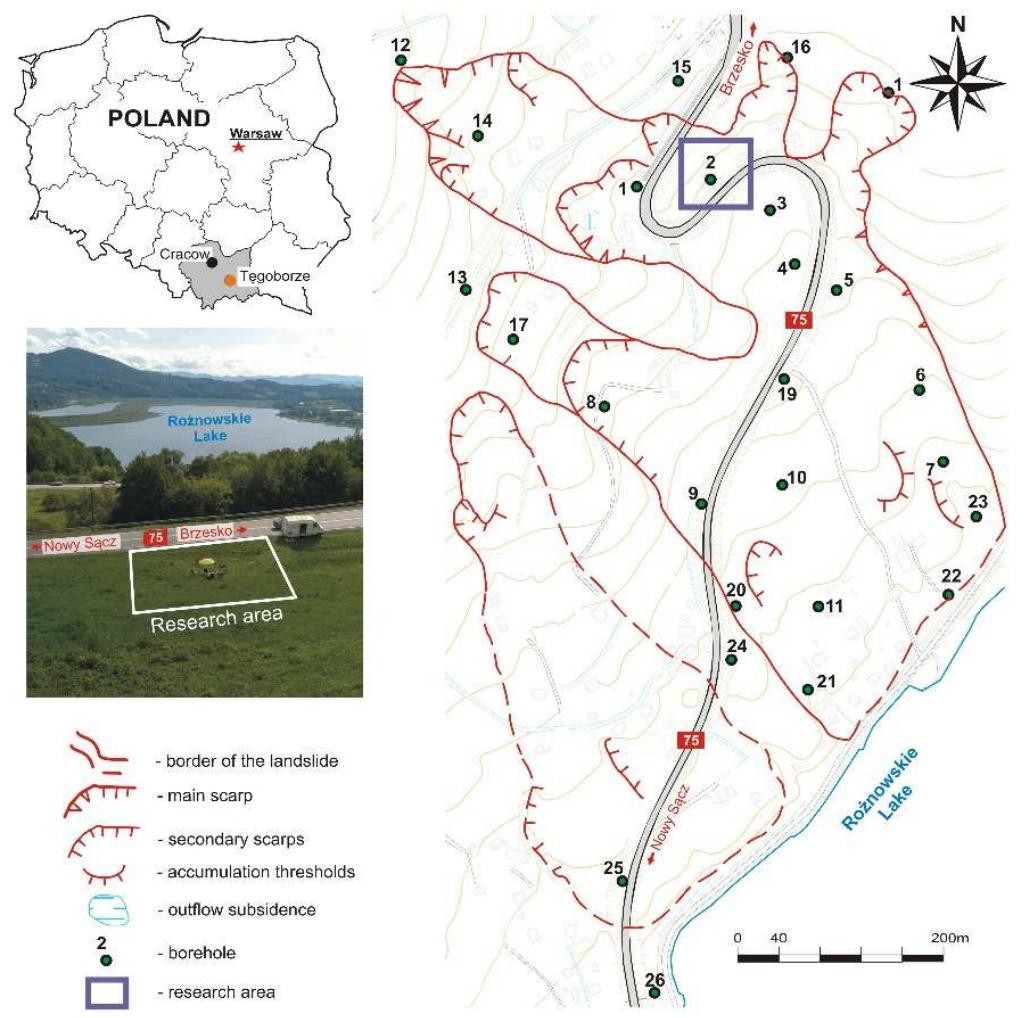

Fig. 1. A situation map showing the border of the Tęgoborze-Just landslide and a general view of the research area.

Measurement of pore pressure in the highly inhomogeneous Carpathian flysch medium is difficult from a technological point of view. The relationship between changes in pore pressure in the geological medium and the development of landslide processes is also complicated. Bednarczyk [6] conducted research into pore pressure changes in order to identify the slip surface in landslides occurring during flysch formation near Gorlice. He developed a monitoring system consisting of pneumatic and vibrating wire sensors of pore pressure, inclinometers, piezometers and an atmospheric station. Bednarczyk [6] confirmed that the development of deformations was associated with an increase in pore pressure in the range from 50 to $100 \mathrm{kPa}$. The increase in pore pressure recorded was particularly noteworthy after the occurrence of intense precipitation above $200-250 \mathrm{~mm}$.

Zabuski [5] studied the changes in water conditions depending on the intensity and duration of precipitation for several landslides occurring during flysch formation in the region of Szymbark. He used 25 open piezometers and systems of inclinometers. Zabuski [5] 
observed that displacements and changes in water conditions were related to the mechanical and hydraulic properties of the geological medium.

Similar studies concerning landslides occurring during flysch formation in the Szymbark region were also conducted by Gil et al. [14]. They observed that the groundwater level decreased for less intense precipitation below $30 \mathrm{~mm}$. For more intense precipitation above $30 \mathrm{~mm}$, the groundwater level increased from $40 \mathrm{~cm}$ to $80 \mathrm{~cm}$. The intense precipitation was also related to the displacement increase recorded on inclinometers.

In the study, geological-engineering conditions in the near-surface part of the Carpathian flysch in the Tęgoborze-Just landslide are presented. The methodology of pore pressure profiling and its limitations are discussed. Finally, we present the results of pore pressure measurements together with inclinometer measurements and their analysis with regard to the identification of a possible slip surface.

\section{Geological - engineering conditions}

The research area is a portion of an active landslide located in Tęgoborze-Just in the south of Poland, about $90 \mathrm{~km}$ south-east of Kraków. Mass movements develop on the south-eastern slopes of the Kamienna and Jaworze mountain range, including the peaks: Jodłowiec Wielki (482 $\mathrm{m}$ a.s.1.) and Saint Just. Geographically, the area is located on the border between two mesoregions: the Beskid Wyspowy and Pogórze Rożnowskie being a part of the Western Outer Carpathians [15] (Fig. 1).

From a tectonic point of view, the research area is located on the border of two thrusting tectonic units - Magura and sub-Magura (grybowska-michalczowej) (Fig. 2). They contain folds and transverse dislocations.

The landslide area is approx. $21.33 \mathrm{ha}$, about $330 \mathrm{~m}$ wide and about $780 \mathrm{~m}$ long. The azimuth of the movement direction is close to $130^{\circ}$, and the average inclination is $11.8^{\circ}$. The landslide is periodically active. In the research area, the bedrock lies at a depth of approx. 24$28 \mathrm{~m}$. Over this layer, a weathering zone is situated which has a thickness of 5-24 m (Fig. 2C). In table 1, we present the parameters of geotechnical layers identified on the TegoborzeJust landslide. These layers are also shown in the geological profile on figure 4.

The main landslide movement takes place in the near-surface zone to a depth of $15.5 \mathrm{~m}$ (Fig. 2C). Within the colluvium, different soil and rock fragments move each other [16]. The effects of the landslide process are visible in the form of the folding and cracking of the road surface. In addition, cracks in the foundations and walls of buildings in the vicinity are also registered.

There is no continuous water level within the landslide colluvium. Its location is variable and related to both the intensity of precipitation and permeability of flysch formation. In the area of the landslide, water leaks are observed.

The measurements were taken in the northern part of the Teqgoborze-Just landslide along national road no. 75 in the area of the 2I/P measuring point (Fig. 2). This point consists of two boreholes used for piezometric and inclinometer tests. At a distance of about $5 \mathrm{~m}$ from the measuring point 2I/P to NE, the borehole $\mathrm{J}-1$ was hand drilled to a depth of $5.5 \mathrm{~m}$ (Fig. 2). In the immediate vicinity of one another, four static sounding CPTU tests were conducted together with the profiling of pore pressure to a depth of about $5.0 \mathrm{~m}$ (Fig. 2A and B). 


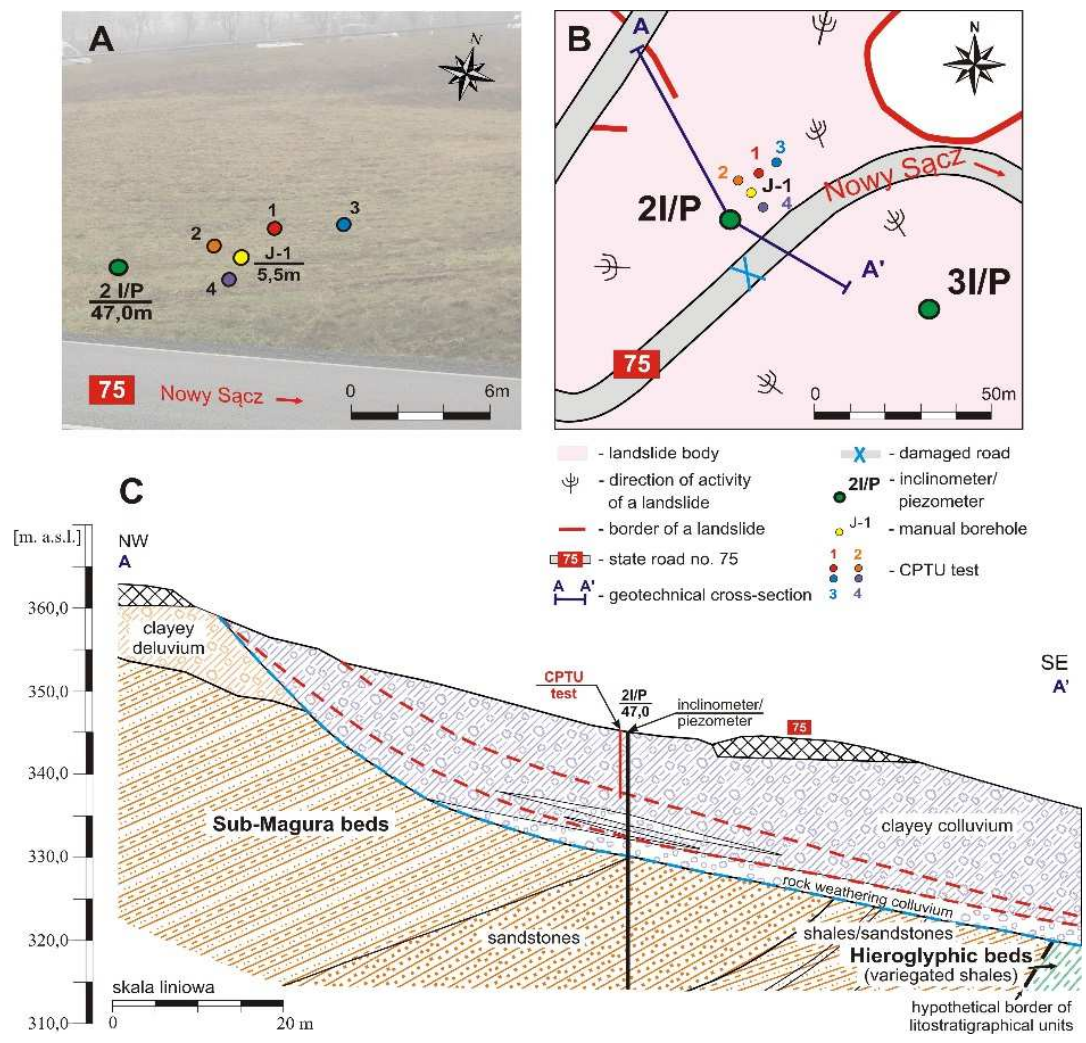

Fig. 2. General view of the research area of the Tegoborze-Just landslide (A), with the scheme of research (B) and the longitudinal geological-engineering crosssection of the landslide (on the basis of [16]) (C).

Table 1. Physical and mechanical parameters of the geotechnical layers (Fig. 4) in the area of the Tęgoborze-Just landslide (on the basis of [16]).

\begin{tabular}{|c|c|c|c|c|c|c|}
\hline $\begin{array}{c}\text { Number of } \\
\text { geotechnical } \\
\text { layer }\end{array}$ & $\begin{array}{l}\text { Type of geotechnical } \\
\text { layer }\end{array}$ & $\begin{array}{l}\text { Plasticity } \\
\text { index }\end{array}$ & $\begin{array}{c}\text { Bulk } \\
\text { density } \\
{\left[\mathrm{Mg} / \mathrm{m}^{3}\right]}\end{array}$ & $\begin{array}{c}\text { Cohesion } \\
{[\mathrm{kPa}]}\end{array}$ & $\begin{array}{c}\text { Angle of } \\
\text { internal friction } \\
\text { [deg] }\end{array}$ & $\begin{array}{c}\text { Uniaxial } \\
\text { compressive } \\
\text { strength } \\
\text { [MPa] }\end{array}$ \\
\hline la & $\begin{array}{l}\text { clayey colluvium: (saclSi, clSi)+ } \\
\text { shale/sandstone }\end{array}$ & semi-solid & $1.90-2.15$ & 23 & 15 & - \\
\hline $\mathrm{lb}$ & $\begin{array}{l}\text { clayey colluvium: (saclSi, cISi)+ } \\
\text { shale/sandstone }\end{array}$ & plastic & $1.90-2.10$ & 18 & 12 & - \\
\hline Ila & $\begin{array}{l}\text { clayey colluvium: (sagrSi)+ } \\
\text { shale/sandstone }\end{array}$ & plastic & $2.00-2.14$ & $23-30$ & $14-21$ & - \\
\hline $\mathrm{Ilb}$ & $\begin{array}{l}\text { clayey colluvium: (sagrSi)+ } \\
\text { shale/sandstone }\end{array}$ & plastic/liquid & $1.90-2.10$ & 16 & 8 & - \\
\hline III & $\begin{array}{l}\text { rock weathering colluvium: } \\
\text { sandstones rubble, breccia }\end{array}$ & - & $2.30-2.44$ & $0-5$ & 32 & $3.5-19.8$ \\
\hline IVa & shales+mudstones & - & $2.31-2.43$ & - & - & $5.5-15.0$ \\
\hline $\mathrm{IVb}$ & sandstones +mudstones & - & $2.14-2.90$ & - & - & $19.0-91.0$ \\
\hline
\end{tabular}

saclSi - sandy,clayey silt $\quad$ clSi - clayey silt sagrSi - sandy, gravelly silt 


\section{Methodology}

Pore pressure profiling was carried out using the static sounding CPTU test of AB Geotech (Sweden). A NOVA Acoustic type electric cone was used (Fig. 3).

The measurement procedure consisted of [17]:

$\circ$ The installation of the measuring set - anchoring and leveling.

- Preparation of a vented filter - it is protected in a container filled with glycerol.

$\circ$ Venting the measuring chamber and filter assembly.

- Connecting the transmitter with the cone and protecting the cone tip with a thin insulation cover.

○ Performing a control measurement.

O Obtaining a profile of the pore pressure.

○ Performing a control measurement.

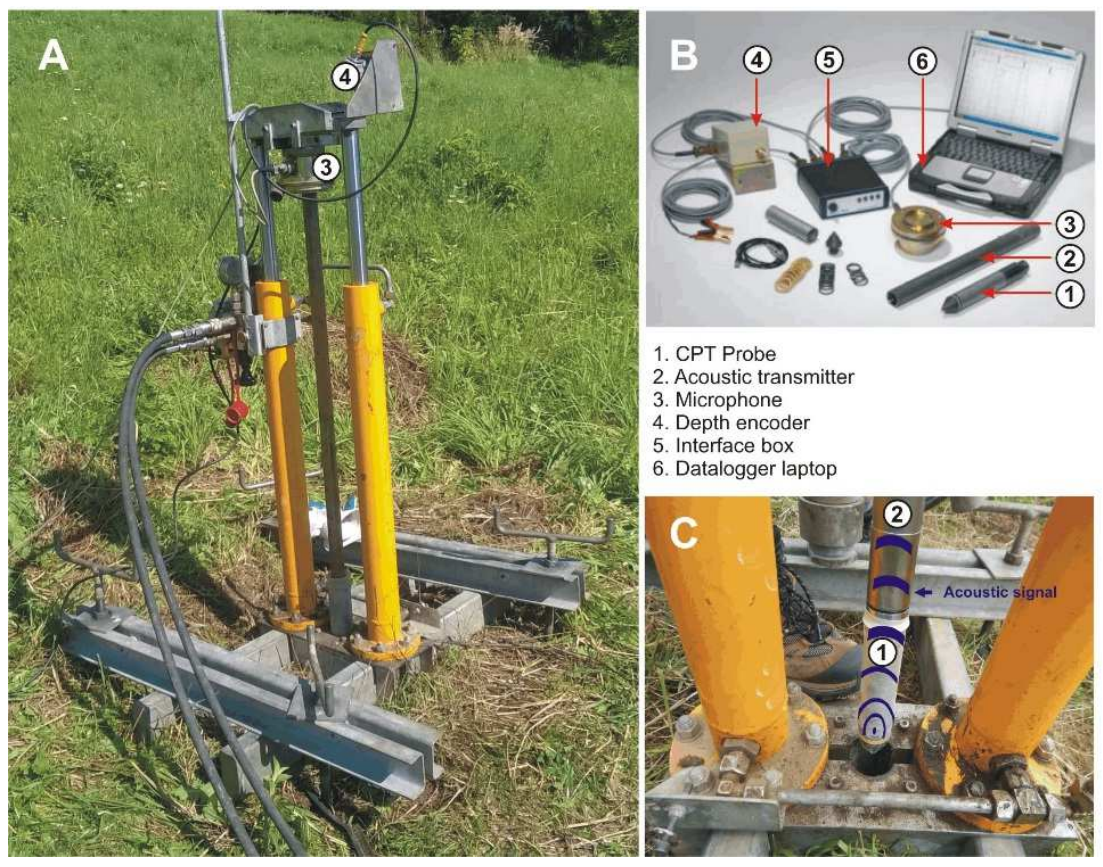

Fig. 3. A view of the CPTU measurement set during a test on the landslide Tegoborze-Just (A), a view of the components of the CPTU measurement set (B) (based on [17]).

The measurement procedure was repeated each time that a new filter was applied. The measurement of the pore pressure was carried out at intervals of $2 \mathrm{~cm}$.

The measurement of pore pressure during static soundings - the CPTU tests, depend on several factors: soil type, the degree of humidity, its stiffness, stress state, preconsolidation, water flow conditions and the degree of geological medium destruction as a result of mass movements [18]. During soundings, the penetration of the cone in the geological medium causes a change in the effective stress and displacement of soil particles and/or rocks. The changes in effective stress are associated with positive or negative pore pressure (suction pressure) $[19,20]$. Below the groundwater table, the soil is fully saturated, and the pore pressure is greater than the atmospheric pressure and it is recorded as a positive value. Above the groundwater table where the soil is partially saturated, the pore pressure is less than the atmospheric pressure and hence is negative in value. The magnitude of the negative pore pressure is determined by the surface tension at the air-water boundaries within the pores and 
is governed by grain size. In general, the finer the soil particles, the larger the saturation capillary head, and hence the greater the negative pore pressure. Precipitation water infiltration may rapidly reduce the magnitude of negative pore pressure [21]. However, the magnitude of negative pore water pressure may vary widely. Any change in this pore pressure alters the shear strength of the soil and therefore has a considerable effect on the slope stability.

A negative pressure may also arise behind the cone tip during the CPTU sounding. This process mainly concerns soils with a solid and semi-solid consistency. The negative pressure in soils with a plastic consistency often leads to the silting-up of the filter.

Bearing in mind the specifics of the measurement of pore pressure, its deep profiling may provide information concerning the location of greater saturation zones or water flow paths. The identified zones may be related with the development of slip surfaces in the geological medium threatened by the landslide process.

In the study, four measurements were realized in 2017. Two measurements designated 1 and 2 were carried out in dry conditions on the 10th and 18th of August 2017. Measurement no. 3 was carried out on the 8th September 2017 after a heavy precipitation of $41 \mathrm{~mm}$. In turn, measurement no. 4 was made immediately after a slight precipitation of $2 \mathrm{~mm}$ on the 11 th of October 2017.

\section{Results and analysis}

The results of the research are shown in Figure 4. Figure 4A presents four graphs of pore pressure changes for each deep profile and a graph of their arithmetic mean changes. Figure 4B presents changes in the average value of pore pressure and inclinometer displacement in two perpendicular directions. The displacement was measured using an inclinometer at the 2I/P measuring point. In general, the pore pressure in all four measurements varied from -86 $\mathrm{kPa}$ to $+47 \mathrm{kPa}$. The maximal positive pore pressure value was measured in dry conditions. The maximal negative value was measured in wet conditions after precipitation. In dry conditions in clayey colluvium, the value of pore pressure was equal $0 \mathrm{kPa}$ to a depth of 1.5 m.

The results of pore pressure measurements have been analyzed for significant positive or negative changes. Such changes may be associated with significant changes in the water content or flow water path. Therefore, such changes may indicate the presence of weak zones that accompany slip surfaces in a geological medium threatened by the landslide process.

On both figures $4 \mathrm{~A}$ and $4 \mathrm{~B}$, four main zones of significant changes in pore pressure may be distinguished, they are numbered from 1 to 4 :

- Zone 1 occurs at a depth of $0.4-0.7 \mathrm{~m}$ (Fig. 4A). In wet conditions, the negative pressure is indicated from -50 to $-10 \mathrm{kPa}$. This is particularly visible on the graph in wet conditions after precipitation of up to $41 \mathrm{~mm}$. In this zone there are silty clays with a plastic consistency. In dry conditions, the pore pressure is equal to $0 \mathrm{kPa}$.

- Zone 2 occurs at a depth of 1.5 to $2.0 \mathrm{~m}$. It is divided into parts a and b, due to contact with silty clays with various consistencies. Pore pressure varies from -82 to $48 \mathrm{kPa}$. A greater value of pore pressure was measured at the bottom of the silty clay layer (b). An increase in pore pressure up to about $48 \mathrm{kPa}$ may be related to the occurrence of shale and sandstone breccia and different water flow paths. In zone 2 a displacement increase of approx. $7 \mathrm{~mm}$ in the $\mathrm{Y}$ direction perpendicular to the longitudinal axis of the landslide was measured. 

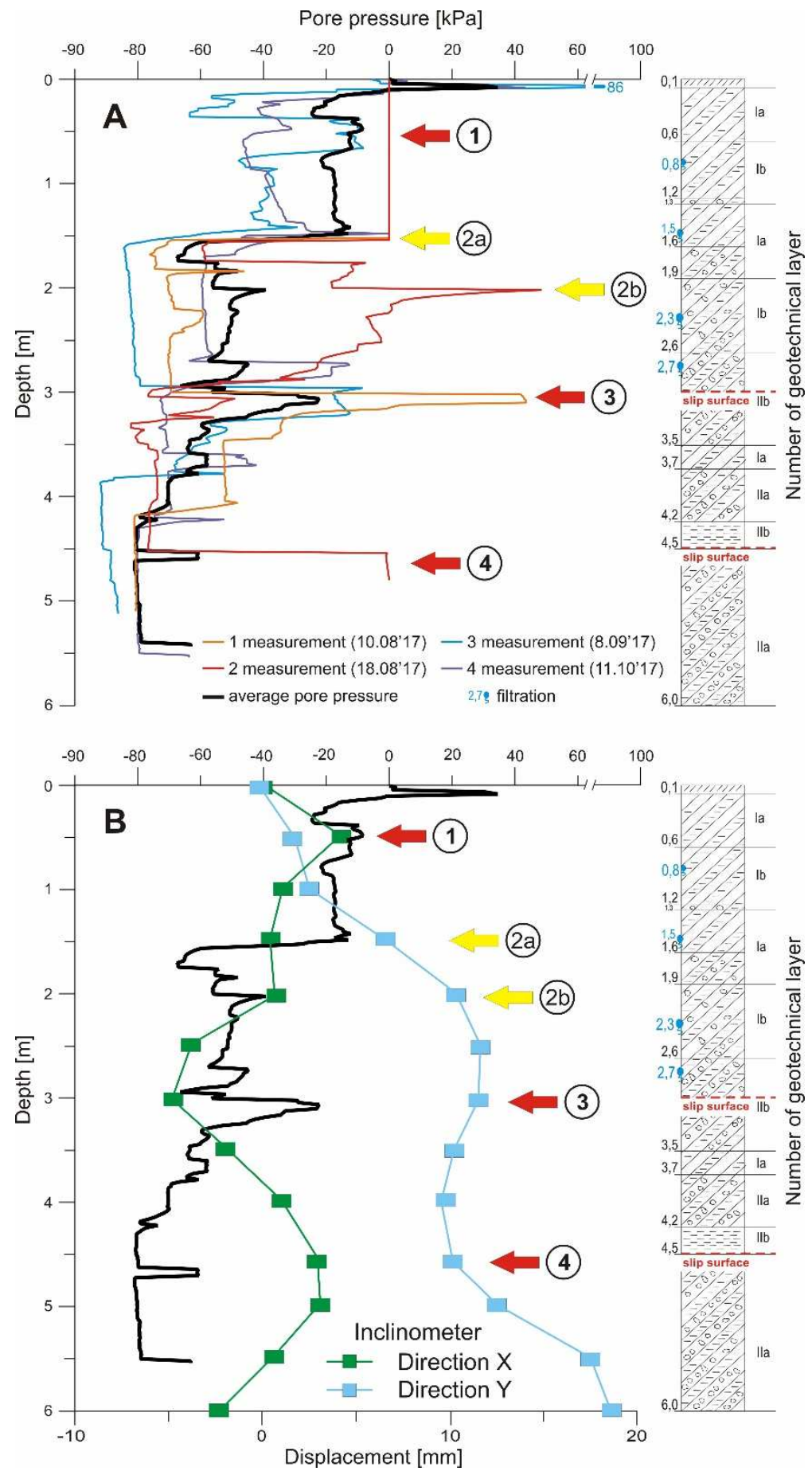

Fig. 4. Graphs of deep profiling of pore pressure changes for four field measurements and changes in the average value of the pore pressure (A); graphs of the average value of the pore pressure and inclinometer displacement (B). On the right hand side, a geological-engineering profile based on the J1 borehole is shown. (Explanations in the text). 
- Zone 3 is characterized by great increases in pore pressure in dry conditions to a value of about $45 \mathrm{kPa}$. An exception occurred in the case of just one measurement, for which no increase in the pore pressure occurred. In wet conditions, the value of the pore pressure varied over a small range from -5 to $-2 \mathrm{kPa}$. The displacements measured with the inclinometer considerably increased by approximately $11 \mathrm{~mm}$, especially in the $\mathrm{X}$ direction along the longitudinal axis of the landslide. The rotational movement was small and amounted to $4 \mathrm{~mm}$. Presumably, zone 3 includes an active slip surface at a depth of approx. $3.0 \mathrm{~m}$.

- In zone 4, at a depth of approx. $4.5 \mathrm{~m}$, the increase in pore pressure in dry conditions was measured. The wet conditions due to precipitation did not cause significant changes in pore pressure. In this zone a great increase of displacement in the $\mathrm{X}$ direction of about $10 \mathrm{~mm}$ was observed. At a depth of $4.5 \mathrm{~m}$, the slip surface was determined based on archival research [16].

\section{Conclusions}

The measurement of pore pressure in the highly heterogeneous colluvial of the Carpathian flysch is difficult to realize and interpret. These difficulties result from the lack of a continuous aquifer in the colluvium of the landslide. Water conditions are variable and closely related to the occurrence and intensity of precipitation as well as the permeability of flysch formation. The relationships between the changes in pore pressure and the development of landslide processes are also complicated.

Based on the four deep profiles of pore pressure and inclinometer measurements in the near-surface colluvium of the Tęgoborze-Just landslide, the following conclusions may be formulated:

1. The static sounding CPTU of AB Geotech with NOVA type electric cones allows for the deep profiling of the pore pressure in the near-surface medium up to about $5 \mathrm{~m}$. In dry conditions, the pore pressure varied from $-82 \mathrm{kPa}$ to $48 \mathrm{kPa}$. In wet conditions with a varied degree of saturation, the pore pressure changed from -85 to $2 \mathrm{kPa}$. Significant changes in the pore pressure values were measured in wet conditions as well as in dry conditions.

2. Four zones of distinct pore pressure changes to a depth of approx. $5.0 \mathrm{~m}$ have been determined. In these zones displacements of different value were registered with the inclinometer. This information allows for the determination of weak zones in which the slip surface of a landslide may develop.

3. The distinct changes in pore pressure are mainly influenced by the type of geological medium (rock/soil), its degree of saturation and degree of medium deterioration by landslide processes.

4. The deep profiling of the pore pressure may be useful in determining weak zones in the near-surface geological medium, even those as complicated as the Carpathian flysch. This information may contribute to a more reliable assessment of the stability of the slope of landslides in the Carpathian flysch.

The research was supported by the Faculty Geology, Geophysics and Environmental Protection of AGH University of Science and Technology, Cracow, Poland, No. 11.11.140.649. 


\section{References}

1. J. Stanisz, Możliwości rozpoznania zagrożenia osuwiskowego na podstawie obserwacji zmian ciśnienia porowego $w$ ośrodku geologicznym (Possibilities of recognition of landslide hazard based on observation of pore pressure changes in a geological medium), Zeszyty Naukowo-Techniczne SITK RP, o. w Krakowie 3 (102), 1-8 (2013) (in Polish)

2. J. Stanisz, Czujniki do pomiaru ciśnienia porowego dla potrzeb rozpoznania położenia powierzchni poslizgu osuwiska (Sensors for pore pressure measuring for identification landslide slip surface), Zeszyty Naukowe IGSMiE PAN 89, 77-91 (2015) (in Polish)

3. Z. Skutnik, M. Biliniak, Suction controlled triaxial testing of unsaturated medium sand and sandy clay, Ann. Warsaw Univ. Life Sci. - SGGW, Land Reclam. 46, 301-307 (2014) doi:10.1515/sggw-2015-0004

4. P. Zawrzykraj, Ocena parametrów filtracyjnych iłów warwowych ze stanowiska Plecewice $k$. Sochaczewa $w$ warunkach in situ (Assessment of permeability parameters of in situ tested varved clays from Plecewice near Sochaczew), Przegląd Geologiczny 65, 587-596 (2017) (in Polish)

5. L. Zabuski, E. Gil, W. Bochenek, Interdependece between groundwater level and displacement of the landslide slope, Polish Geol. Inst. Spec. Pap. 15, 39-42 (2004)

6. Z. Bednarczyk, Monitoring of Rainfall Induced Landslides in Relation to Weather Conditions at Selected Locations in Polish Carpathians, In: Lollino G. et al. (eds.) Engineering Geology for Society and Territory - Volume 2 (2015) doi: 10.1007/978-3319-09057-3_207

7. P. Harba, Z. Pilecki, Assessment of time-spatial changes of shear wave velocities of flysch formation prone to mass movements by seismic interferometry with use of ambient noise, Landslide 14, 1225-1233 (2017) doi: 10.1007/s10346-016-0779-2

8. J. Stanisz, P. Krokoszyński, R. Kaczmarczyk, Impact of precipitation on dissipation of pore pressure in colluvium of the Carpathian Flysch landslide, Proc.of China-Europe Conference on Geotechnical Engineering (2018) doi: 10.1007/978-3-319-97115-5_138

9. K. Thiel, Ksztaltowanie fliszowych stoków karpackich przez ruchy masowe (Formation of flysch Carpathian slopes by mass movements), Prace Instytutu Budownictwa Wodnego PAN Gdańsk (1989) (in Polish)

10. J. Dziewański, Z. Pilecki, W. Sroczyński, Zagadnienia badań geologiczno-inżynierskich $w$ projektowaniu tuneli komunikacyjnych w utworach fliszu karpackiego na przykładzie tunelu $w$ Lalikach (Geological-engineering research in the design of transportation tunnels in the Carpathian flysch on the example of a tunnel in Laliki), Studia, Rozprawy, Monografie 96, Wyd. IGSMiE PAN, Kraków, 64 (2001) (in Polish)

11. Z. Pilecki, Basic principles for the identification of landslides using geophysical methods E3S Web Conf. 24, 01001 (2017) doi: 10.1051/e3sconf/20172401001

12. H. Marcak, Z. Pilecki (eds.),Wyznaczanie właściwości utworów fliszu karpackiego metoda sejsmiczna dla potrzeb budownictwa tunelowego (Determination of properties of the Carpathian flysch rocks using the seismic method for the needs of tunnel construction), Wyd. IGSMiE PAN, Kraków (2003) (in Polish)

13. T. Majcherczyk, Z. Pilecki, Z. Niedbalski, E. Pilecka, M. Blajer, J. Pszonka: Wptyw warunków geologiczno-inżynierskich i geotechnicznych na dobór parametrów obudowy wstepnej tunelu drogowego $w$ Lalikach (Influence of geological engineering and 
geotechnical conditions on the selection of parameters of preliminary support for a road tunnel in Laliki), Gospodarka Surowcami Mineralnymi 28/1, 103-124 (2012) (in Polish)

14. E. Gil, L. Zabuski, T. Mrozek, Hydrometeorological conditions and their relation to landslide processes in the Polish Flysch Carpathians (an example of Szymbark area), Studia Geomorphologica Carpatho-Balcanica 43, 127-143 (2009)

15. T. Ziętara, Obszary osuwiskowe $w$ dolinie Dunajca nad Jeziorem Rożnowskim (Landslide areas in the Dunajec Valley on the Rożnowskie Lake), Rocz. Sądecki 14 (1974) (in Polish)

16. G. Czudec, J. Bulanda, I. Andrasik, W. Kawa, Z. Paul, Z. Bestyński, J. Bulanda, D. Mach, P. Gawron, J. Ryznar, C. Biskup, P. Jurczyk, A. Gałus, M. Gruca, Dokumentacja geologiczno-inżynierska dla opracowania systemu zabezpieczenia strefy osuwiskowej $n r$ MPL0051, w ciagu drogi krajowej $\mathrm{nr} 75, \mathrm{~km}$ od 51+900 do 52+700 w miejscowości Tegoborze-Just (Geological and engineering documentation for the development of the landslide protection system No. MPL0051, along the national road No. 75, $\mathrm{km}$ from 51 900 to 52700 in the town of Tegoborze-Just) (2012) (in Polish)

17. Z. Sikora, Sondowanie statyczne. Metody $i$ zastosowanie $w$ geoinżynierii (Static sounding. Methods and application in geoengineering (2006) (in Polish)

18. R. G. Campanella, P. K. Robertson, D. Gillespie, Factors affecting the pore water pressure and its measurement around a penetrating cone, $39^{\text {th }}$ Canadian Geotechnical Conference, Ottawa (1986)

19. K. Terzaghi, Die Berechnung der Durchlassigkeitsziffer des Tones aus dem Verlauf der hydrodynamische Spannungserscheinungen, Abt. Iia Sitzungsber. Akad. Wiss, Wien (1923)

20. J. E. Jennings, J. B. Burland, Limitations to the use of effective stresses in partly saturated soils, Geotechnique 12, 125-144 (1962)

21. N. Lu, W. Likos, Unsaturated soil mechanics, John Wiley and Sons Inc., New York (2004) 